\title{
Introduction: Gender, Space, and Affects in Film
}

When we look for films that 'imagine' mobile female characters and examine the scholarship related to these films, we encounter binaries in both, binaries that confine women through gendered considerations of mobility. Filmic narratives of travel, such as the road movie, tend to situate their characters within dichotomous systems that oppose, for instance, 'masculine' / 'feminine', mobility / stasis, road / house, traveller / strayed wanderer, ${ }^{1}$ desiring / aimless, and autonomy / dependency. Meanwhile, scholars writing about gender and space on screen also seem to overtly focus upon how female characters seem trapped in both passive roles and within domestic space. Having noted the prevalence of binaries, we need to ask how the patriarchal status quo affects women's (as in those who identify or are identified as 'women') freedom of movement and habitation of space.

In this book I am looking for both 'new images' that will transmit women's wilful habitation of space along with a new vocabulary through which to theorise gender and space in film affectively. The logical starting point, with the road movie, is in fact problematic for female protagonists for reasons I discuss in Chap. 2; therefore, what we need to examine is not the 'mobility' of these women but their bodily habitation of their spatial environments. Similarly, in order to find wilful models of women who are able to move and act with as much 'freedom' as men do, we have to start looking at 'mobility' through a different lens. ${ }^{2}$ For what stands out from 
the real-life stories in my preface is the 'problem' that bodies indentified as female seem to pose to patriarchal societies.

The way mobility is perceived and analysed in the cinema needs to change. Departing from the romantic and gendered aspects of travel, the freedom found on the road, or the seemingly transformative potential of mobility can instead be found in the habitation of space itself, of spaces currently dominated or controlled by men, such as the ones I consider in this book: the street, the house, and the car. Rather than forming a distinct category of works or a filmic genre, the films examined here are examples of films that show women's spatial habitation as 'affirmative', a term to which I will return; hence, the women characters in the films studied break away from the spatial and gendered binaries that maintain them on the 'right path' under patriarchy. From this starting point the book follows two ideas: first, we take a journey into filmic (affective) representations of women's spatialities; second, we look for an appropriate language to extract affirmative movement from these representations, evacuating the negativity that has continually re-placed women within binary models of gender and mobility. Wilfulness, habitation, affirmative, and affective are some of the key terms through which a model for gender and space in cinema will be plotted in order to recognise the fluidity, affectivity, and plurality of spaces and subjectivities. To begin, it is necessary to rehearse some of the critical terrain upon which this book builds. This introductory chapter is divided into two parts. The first part provides a methodological journey through which I explore the ideas of space as a kind of space-time that is in continual transformation, examine how cinema produces transformative affects and discourses, and consider how spaces on screen are created through filmic forms and bodies. In the second part, I return to the terms that I introduce here and adopt Rosi Braidotti's affirmative politics and Sara Ahmed's wilfulness as ways to analyse women's wanderings from prescribed paths and habitation of different spaces as affirmations of fluid identities. I refer to fluid as unbounded; the representation of characters' subjectivities is essentially liminal, on thresholds, and in continual transformation, rather than bound to fixed categories of gender, race, space, or sexuality.

If we retrace scholarship on gender and space, we typically find ourselves back at the turn of the twentieth century, out in the streets, in an emerging public sphere. Due to their continual sexualisation, women had to deploy several tactics to inhabit the public sphere. In her revision of her essay 'The invisible flâneuse' (1985), Janet Wolff highlights how only men 
had 'the privilege of passing unnoticed in the city' while women's 'presence on the streets would certainly be noticed' $(2006,19)$. Women's difficult habitation of space is opposed to the privileged abilities of men to cross spatial boundaries unrestricted. While male flâneurs such as Baudelaire were roaming the streets for pleasure or in search of artistic inspiration, female flâneuses, such as Virginia Woolf, needed a clear aim that justified their movement in so-called 'public' spaces (1942). As has been well recorded, middle-class female flânerie became possible with the apparition of the department store, as it allowed women to go into the streets unchaperoned, and consume goods in a semi-private, protected area. ${ }^{3}$ As Rebecca Solnit puts it in her book Wanderlust, 'women legitimised their presence [in urban life] by shopping-proving they were not for purchase by purchasing... as either commodities or consumers' (2001, 237).

For many of these early writers, the streets were seen to have a negative impact upon women's lives. Ironically, in order to escape the commodifying male gaze, women had to haunt the urban space like unwelcome ghosts, ${ }^{4}$ for they embodied all the sexual 'uncanny' that the city space represented (Wolff 2006, 27). In particular, Wolff notes that:

the lives of women in the modern city-in private as well as in public (for the sociology of modernity has paid little attention to the domestic sphere) are thus, as [Avery] Gordon puts it, 'barely visible, or seemingly not there'. As a result, they haunt the discourse and the city itself-uncanny because not admitted to language and thought. $(2006,27)$

Despite the tendency to dwell upon the problems city spaces pose to women, less pessimistic readings do exist. Elizabeth Wilson describes how women's resistance to ideological and spatial boundaries 'flourished in the interstices of the city' (1991, 8, emphasis mine). Whereas Wilson writes that cities of the early twentieth century were simultaneously feared and desired for all the sexually and morally forbidden activities that became possible, and that women were (and arguably continue to be) seen as problems that needed to be controlled. Yet Wilson also celebrates the potential of cities to offer women, in particular, 'greater freedom and diversity than life in small communities' $(5-6 ; 156)$. Although in the city '[women] were and continued to be defined in terms of their sexuality in a way that most men were not', urban life undermined patriarchal authority, as it gave birth to employment and subsequent relative economic independence, as well 
as entertainment, with all the ideas of immorality and illegitimacy that it conveyed $(2001,137 ; 73) .{ }^{5}$ In her work, Wilson identifies acts of resistance that bring about transformative practices and affirmative narratives of space.

A reading of gender and space that begins with the flâneur leads us down the cul-de-sac of binaries to which I referred earlier. Such discourses emphasise women as being negatively affected and unable to transform their negative affection into productive forces, as Rosi Braidotti would advocate. Braidotti's work on 'affirmative politics' echoes my frustration with critical theory that is anchored in negation, in 'quests for meaning' (Braidotti 201 la, 292); instead, Braidotti advocates '[starting] from micro-instances of embodied and embedded self and the complex web of social relations that compose the self... [building] upon micropolitical instances of activism, avoiding overarching generalisations' (201 lb, 268-69, emphasis mine). In an article titled 'The new activism: A plea for affirmative ethics', Braidotti advocates '[actively working] towards the creation of alternatives ... [thereby] abandoning dualistic oppositional thinking ... [and creating] an ethology of forces ... not tied to the present by negation' $(2011 b, 267)$. Through 'untapped' resources such as 'desires and imagination', Braidotti champions thinking differently about ourselves and others, in a non-dichotomous way, as 'a question of and/and, not of either/or' (268). Her call for 'affirmative ethics' aims to establish 'transformative politics' and 'sustainable futures' by rewriting a new 'cartography' (270). ${ }^{6}$ Similarly, transformations of women's spatial imaginaries beyond patriarchal boundaries rely upon a combination of wilful and imaginative spatial habitation on screen and affirmative ways of considering them. Affirmative aesthetics on screen and in the scholarship amounts to 'enduring' patriarchal systems rather than being 'dispossessed' by them (in Braidotti's words). In her book Nomadic theory, Braidotti writes that affirmative ethics produce:

a number of significant shifts: from negative to affirmative affects, from entropic to generative desire, from incomprehensible to virtual events to be actualised, from constitutive outsides to a geometry of affects that require mutual actualisation and synchronisation, from a melancholy and split to an open-ended weblike subject, from the epistemological to the ontological turn in philosophy. (2011a, 290)

For Braidotti, affirmative ethics functions as a way to relate to life through its 'potentia', its 'generative force of becoming', instead of through what she calls 'negative passions' such as entropy or melancholy, 
in other words, yielding to negative affects 'as a result of a blow, a shock, an act of violence, betrayal, trauma, or just intense boredom' (201 la, 288).

My approach to gender and space makes visible what I call affirmative aesthetics, as a cinematic way out of the restrictive dualistic oppositions that freeze the present into negative politics. The films chosen, Messidor (Alain Tanner 1995 [1979]), Vendredi soir (Claire Denis 2002), Wadjda (Haifaa Al-Mansour 2012), and Head-On (Fatih Akin 2004) enable the study of women's micro-relations to space through an 'affirmative' lens, examining their bodily and affective spatial relations rather than focusing upon the (lack of) 'success' of their travel. However, as the recourse to Braidotti might suggest, such an approach demands that the tools of film studies are combined with those of other disciplines-namely cultural geography and feminist critical theory-so as to reconceive of space as space-time and to understand the affective dimensions of spatial relations.

\section{An Inter-Disciplinary Approach to Mobility, Space, AND Gender on SCREen}

In the search for an affirmative vocabulary through an examination of the body's relation to space as lived experience, we need to consider space as fluid, practised, and affective rather than conceived and fixed. Feminist geographer Doreen Massey's concepts of space-time and power-geometries offer useful starting points.

\section{Space-Time and Power-Geometries}

Narratives and affective images 'involving' relations to space, such as the street, the house, and the car in particular, affect how people experience and inhabit these spaces. Spaces exist in time and in representation: they are lived through historical and affective imaginaries. For Henri Lefebvre, spaces are threefold: an interweaving of this 'lived space' (espace vécu) just mentioned, the space 'conceived' (l'espace conçu) by planners and urbanists, and the space 'perceived' (l'espace perçu) through daily practices (Lefebvre 1974, 49-52). Although space is conditioned by how places were initially conceived and by current practices (with all the restrictions of mobility related to gender, class, and 'race'), films produce spatial imaginaries - or in Lefebvre's words, lived spaces, 'spaces of representation'within which processes of change may occur. We are not interested here in the 'conceived space', which implies planning and regulations, but in 
the lived space, made of social relations that continually change through time, as defined by Doreen Massey. The three spaces that Lefebvre distinguishes are contingent, so that one could consider that filmic representations of space and bodies have an impact on lived, perceived and, ultimately, conceived places.

In this book, I refer to space as 'practiced places', socially constructed and in constant transformation (de Certeau 1984, 117). For Michel de Certeau, narratives constantly transform places into spaces and, vice versa, the social idea of a space into a specific place (118). De Certeau explains that these narratives emerge as strategies, deeds of a 'subject of will and power (a proprietor, an enterprise, a city, a scientific institution)', or as tactics, the weak's (the 'other') resistance to hegemonic structures (xix). It seems here that strategies conceive space and participate in the perception of space, while tactics progressively determine lived spaces. According to de Certeau, the binary separation of space that depends on actions of the strong and the weak impacts how space and time are perceived, ranked, and appropriated: strategies are spatialised and tactics depend on time.

In the essay collection Entanglements of Power: Geographies of Domination/Resistance (2000), Tim Cresswell and Doreen Massey critique de Certeau's binary divisions between strategies and tactics, and domination and resistance. As opposed to subjects 'with will and power' managing space and its inhabitants, de Certeau describes very pessimistically the position of the 'weak', or the 'other', who lacks a proper place and can only resist strategies of power through micro-tactics (1984, 36-37). Massey argues that a more 'egalitarian map of power' requires thinking about power in terms of both possibilities and responsibilities by practising 'active spaces of action, [which are] continually being made' $(2000,284)$. While power configurations are not as totalising and allcoherent as de Certeau argues, Massey warns: 'a recognition that power is everywhere - and that we must pay attention to the micro-politics of power (which we must) - should not lead to a position where the real structural inequalities of power are lost, dissipated in a plethora of multiplicities' (280).

According to Massey, space should be considered as space-time affected by 'power-geometries': a practised, inhabited, and 'ever-shifting social geometry of power and signification' $(1994,3)$. Massey contends that space is not neutral, 'fixed and unproblematic in its identity' (5), but is instead an evolving source of meaning and social relations produced and reproduced within power configurations. While these power-geometries 
may seem immutably established within social relations, fixed in time, it is essential to retain Massey's idea that space always remains in a continual process of becoming. In her essay 'A global sense of place', Massey argues that not only 'capital' but also race and gender characterise our sense of space, time, and mobility (1994, 147). She describes our 'sense of place' as a place of rootedness as well as a progressive sense of place that accounts for our current 'global-local times', and the networks of power and control over mobility present within places and communities (150-52). Although people's sense of place often relates to their need for attachment, Massey contends that space should be detached from reactionary nationalisms, obsessions with 'heritage', or the idea that it conveys unproblematic stable identities (151). Instead, what matters is a 'geography of social relations': thinking of places as 'articulated moments in networks of social relations and understandings' not restricted by boundaries but positively linked to a consciousness of the wider world (Massey 1994, 154-55). Massey defines the concept of place as follows:

what gives a place its specificity is not some long internalized history but the fact that it is constructed out of a particular constellation of social relations, meeting and weaving together at a particular locus.... [Place] is absolutely not static. If places can be conceptualised in terms of the social interactions which they tie together, then it is also the case that these interactions themselves are not motionless things, frozen in time. They are processes. ... places are processes, too.... clearly places do not have single, unique 'identities'; they are full of internal conflicts. (1994, 154-55)

Cultural geographers have provided the tools to reconsider places that were previously seen as unproblematic (such as streets, houses, and cars) in a framework that considers the dynamic socialities of gender, class, 'race', and culture (Massey 1994, 2000; Rose 1993; McDowell 1999; Spain 1992; Thrift 2008; Uteng, and Cresswell 2008). ${ }^{7}$ In her reformulation of space as social and contextual, Massey powerfully advocates the need to consider space as 'space-time', since the spatial is interrelated with the social, on a local and a global scale, and 'is integral to the production of history, and thus to the possibility of the politics' $(1994,269)$. Later I will argue that we should perceive of gender as a social construct and a foundation for unequal power-geometries rather than as a valid category of identity; similarly, we must reject the binaries that separate public from private, home from travel, and space from time. ${ }^{8}$ Instead, space must be considered as in continual transformation, a 
transformation that, I argue, may occur through films, among many other sociocultural instances. In the next section, I explore the affectivity of spatial habitation, which films build upon, thereby making and remaking space.

\section{Forms, Bodies, and Affects on Screen}

If we are to see space as in continual transformation and constructed through fluid social relations, as Massey and Lefebvre argue, then we also need to understand that space is constructed through the affects (human and non-human) bodies have on one another. The recent (re)turn to affect theory in screen studies seems appropriate to account for the embodied aspect of power dynamics beyond binary patriarchal narratives, especially seen through the lenses of feminist scholars of affect (see Ahmed 2004, 2010; Berlant 2011; Brennan 2004; Butler 1997; Hemmings 2005; Sedgwick 2003; Stewart 2007). ${ }^{9}$

For Brian Massumi, affect encompasses three interrelated dimensions: a personal but collective bodily experience, a present potential to experience life, and an affective reflection. Massumi follows Baruch Spinoza's definition of affect: 'emotions (affectus)... [are] the affections of the body by which the body's power of activity is increased or diminished, assisted or checked, together with the ideas of these affections' (1982 [1677], 104). There is, in Spinoza, the double notion of being affected (having a decrease or increase of power of activity) and the accumulation of these affects. Cinema creates affects insofar as it is a mediated form, or in Lauren Berlant's words in Cruel Optimism, a 'recording form [that] not only archive[s] what is being lost but track[s] what happens in the time that we inhabit' $(2011,7)$.

Films aesthetically produce affects as they give shape to space and bodies. Following Massumi and Teresa Brennan, Lauren Berlant writes that 'bodies are continually busy judging their environments and responding to the atmospheres in which they find themselves' $(2011,15)$. If we consider the film as a body similar to the ones of the characters (see Barker 2009), the film embodies affects that give shape to space, characters, and situations. As the camera changes angle or lets in more or less light, for instance, it gives form to specific affects (see Brinkema 2014). In fact, when Spinoza refers to affecting and affective bodies, he is not only referring to the affect one human body can have on another, but also to affects produced by and to non-human bodies, objects, situations, and processes. Referring to Spinoza, Massumi explains that affect is 'the experience of a change, an 
affecting-being affected, redoubled by an experience of the experience' $(2002,4) \cdot{ }^{10}$ In other words, affect is the body's transiting 'power of activity' and the experience of that transition: a bodily experience that is at once personal and collective, affecting, and affected.

If affect is personal because people are individually affected in their own way, it is also collective because events or situations affect people collectively and have a similar bodily impact on a group of bodies, bodies that collectively affect each other (see Brennan 2004). Affects then form a 'visceral' memory that conditions our actions and reactions; this memory takes aesthetic forms on screen and may ultimately contribute to the building of collective cultural affects. Affects accumulate as 'perpetual bodily remainders', which 'expand our emotional register, or limber up our thinking', building potential 'ways of connecting', 'angles of participation in processes larger than ourselves' (Massumi 2002, 7; 5). In this sense, affect is potential, using a Deleuzian vocabulary, it is 'the virtual co-presence of potential' (5); in other words, accumulated ways of living that can become actualised. In Deleuze's interpretation of Spinoza, affect (affectus) is variation, 'the continuous variation of the will to exist (or the power of activity) of an individual, a variation that is determined by the 'ideas' that one has' (Deleuze 1978-1981, 9), ${ }^{11}$ and is thus determined by previous affects. This brings us to another dimension of affect, as 'thinking, bodily', a 'thinking movement', 'the passing awareness of being at a threshold', which is not reflection (Massumi 2002, 8), but which, I argue, informs our consciousness and continually, subconsciously, transforms the ways in which we act, think, reflect, react, and feel, in the present. As Spinoza writes, 'whatsoever increases or diminishes, assists or checks, the power of activity of our body, the idea of the said thing increases or diminishes, assists or checks the power of thought of our mind', and transforms our imaginaries (Spinoza 1982 [1677], 111). ${ }^{12}$

Massumi explains that emotion and conscious thought are 'very partial [expressions] of affect', as 'the way we live... is always entirely embodied, and... is never entirely personal-it's never all contained in our emotions and conscious thoughts' $(2002,4 ; 5)$. In my embodied position as a spectator and as a researcher, the affects films produce-or embody-may modify such (affective) positions as suggested in the preface of this book; film may thus modify our 'margin of manoeuvrability, the "where we might be able to go and what we might be able to do" in every present situation' (in Massumi's words, 3). In the films I explore, affects take form through space and bodies, as aesthetic and narrative passages and 
connections. Similarly to Natalie Fullwood's work on gender and space in Italian cinema, this book explores 'how ideas of gender affect profilmic [that is, the spaces in the world chosen for settings] and filmic [that is, fictional, cinematic images] spaces, and the relation between the two' (2015, 5-6). Affirmative Aesthetics and Wilful Women, however, takes a reversed approach, as it considers how cinematic constructions of space and bodies give form to fluid genders, and everyday spaces (what Fullwood calls 'profilmic' spaces).

I disagree with Massumi's take on affect as asocial and outside discourse. Instead, I concur with Clare Hemming's idea that affect does not exist outside of social relations. Along with Lauren Berlant (1997), Audre Lorde (1984), Franz Fanon (1967 [1952]), and Sara Ahmed (2004), Hemmings emphasises that 'affective responses are bound by the early contexts in which [we] learn the codes and practices of gender and sexuality', among other social practices $(2005,560)$. Hemmings adds that certain subjects 'are so over-associated with affect that they themselves are the object of affective transfer', such as through sexualisation and racialisation (561). Hemmings refers to Jennifer Biddle's example of the woman prostitute, who has been inflected with being shameless, and to Franz Fanon's and Audre Lorde's accounts of black bodies as inspiring disgust in others and thus being affected with shame. As an example of affect, shame and disgust are linked to the social world through an 'ongoing, increasingly altering chain - body - affect - emotion - affect - body—doubling back upon the body and influencing the individual's capacity to act in the world' (Hemmings 2005, 564). Lorde's response to the ongoing spiral of shame may be interpreted as a wilful response, and as such, as an affirmative political act, whereby she 'reinvents her body as hers not theirs [such as through the erotic as Lorde argues elsewhere (1984) ]... and connects to other bodies by shared judgments of the social' (Hemmings 2005, 564). As we will see throughout the book, and as Chap. 5 explores in more detail, the accumulation of negative affects (for instance as a woman, who is not accommodated by patriarchal structures) has an impact on one's habitation of space and gives form to space and bodies on screen. As Lorde's story exemplifies, these affects can also be appropriated and transformed (although not necessarily consciously), and thereby take affirmative forms.

In her book The Cultural Politics of Emotion, Sara Ahmed also interweaves affects with social relations and discourses. As she puts it, 'emotions shape the very surfaces of bodies, which take shape through the repetition of actions over time, as well as through orientation towards and away from others' (Ahmed 2004, 4). Affects orient our bodies into space, 
both through the presentness of the situation-the bodies we encounter-and how we are made to feel: our intentional emotions, which 'move us "toward" and "away" from such objects [we come into contact with]', in Ahmed's words $(2006,2) .{ }^{13}$ In her book Queer Phenomenology (2006), Ahmed writes that bodies also take different shapes as they are being nominalised. Drawing on Butler's and Althusser's work on nominalisation, Ahmed explains that 'hearing oneself as the subject of [a gendered, sexualised or racialised] address' forces upon the subject a particular view of the world, orients bodies in a certain direction while hiding other directions from view (15). The body's power and will to persevere in a certain direction is in continual transformation, depending on how one affects and is affected by other human and non-human bodies. Certain spatial encounters and situations may create new connections and new ways of reaching out, and thereby turn the body in a different direction. As Ahmed eloquently describes in her later book Willful Subjects (2014), the subject may, for example, experience wilfulness out of not being accommodated. ${ }^{14}$ Wilfulness may bring into sight lines and paths that have disappeared or have been concealed from view. Bringing these lines into view on screen, as I argue throughout this book, is affirmative, in so far as it reaffirms the fluidity of experience, and social and spatial relations.

In his second cinema book L'image-temps, Gilles Deleuze explains that film works as a mind, as a consciousness of the world and provokes a creative thinking towards the world, the unthought, the unseen $(1985,218)$. For Deleuze, through cinematic time ('durational' shots), film activates potentialities of the world which we fail to see in reality, producing a thinking towards the 'virtualities' within the real, in a similar manner as other philosophical 'tools' (see also Claire Colebrook 2000). Prior to this book, in Différence et répétition, Deleuze takes up the Bergsonian idea of 'duration' to explore continuous change, the process of becoming that things undergo through time (1976). Along the same lines, Elizabeth Grosz explains that 'each object is more than itself, contains within itself the material potential to be otherwise' $(2005,10) .{ }^{15}$ Deleuze and Grosz argue that the real contains endless virtualities, the present being thus unfixed, ever-altering, and always in becoming; Deleuze adds, however, that the actualised form of these virtualities in the present space-time makes them appear (mistakenly) fixed and immutable (1976). Following Deleuze's thoughts, filmic representation may present both a version of reality that seems fixed and immutable and the virtualities of the same reality. While cinema has the potential to fix spatial habitation within racialised and 
gendered ideas, it may also affirmatively suspend these ideas of space and bodies and actualise alternative forms.

Following the notions of affect and cinema developed by Deleuze, Massumi, Berlant, Hemmings, and Ahmed, I would like to conclude that cinema acts as a 'way of thinking' towards the world and towards socio-spatial power relations. Although realist cinema is anchored in the actually existing, it may also reveal other perspectives: of a world in constant transformation. This book adopts Spinoza's and Deleuze's reading of affect as non-representative thought, as duration, as a passage: 'the continuous variation or the passage from one degree of reality to the next' (Deleuze 1978-1981, 10, translation mine). ${ }^{16}$ In film theory, affect has often been considered as being there for the spectator, or as an exchange of potentialities between film and spectators (Sobchack 1992, 2004; Barker 2009). As Steven Shaviro writes, many film theorists have linked cinema and other media and art works to the production of affects, as 'machines for generating affect, and for capitalizing upon, or extracting value from, this affect... [films and music videos] lie at the very heart of social production, circulation, and distribution. They generate subjectivity' (Shaviro $2010,2-3$, emphasis in original). Rather than concentrating on the potential exchanges between film and viewers, this book focuses on the textures, light, objects, colours, sounds, and bodies that give shape to the film world, to space on screen. In his book Non-Representational Theory: Space, Politics, Affect, Nigel Thrift argues that it is by going beyond representation, beyond anchoring narratives and dialogues, that space, time, and gendered bodies become reconfigured (2008, 113-119). It is by focusing on affects as filmic forms that we can sense how this happens. In the genre of musicals, Richard Dyer finds great importance in recognising how 'non-representational signs' (colour, texture, movement, rhythm, melody, camerawork) 'embody feeling' and 'suggests an alternative to the narrative' (Dyer 2002 [1992], 21; 28). I contend that cinematic forms may create affirmative 'cracks' in the patriarchy that emerges from realist narratives; they may create what entertainment offers for Dyer: 'what utopia would feel like rather than how it would be organized' (20, emphasis mine). On a similar line, Eugenie Brinkema's model of close analysis ('reading for form') is appealing. In an authoritative and convincing manner, Brinkema writes in favour of 'treating affects as structures that work through formal means, as consisting in their formal dimensions (as line, light, color, rhythm, and so on) of passionate structures' $(2014,37)$. In her formalist film analyses, Brinkema reads affects as 'a matter of form, 
composition and structure [that] requires leaving behind narrative thematics', looking for the 'affective commitment' of a film (99). Her book The Forms of the Affects (2014) opens with detaching Marion's tear in Hitchcock's film Psycho from what it generally invokes: an emotional expression, a symptom of sadness. Brinkema reads the tear as form, as a structure: 'a texture', 'a distortion or culmination of pattern', or 'a method of reflecting light' (21). The tear becomes a form of affect, the form of a 'force more than transmission, a force that does not have to move from subject to object but may fold back, rebound, recursively amplify' (Brinkema 2014, 24). Reading affects as forms amounts to looking at virtual potentialities, at how transitions within space and bodies take shape on screen. Wilful affects should thus not be read as conscious mobilisation of the body against patriarchal dominance or oppressive representation, but rather as openness, transitions, and aesthetic actualisation of the virtual possibilities that exist within the real, and create the new against dichotomies of gender, space, and power.

\section{Affective Cinematic Spaces}

In this book, I regard characters and films as bodies of affects that constitute space. In his article 'On the role of affect and practice in the production of place', Cameron Duff underlines the recent turn whereby 'affects come to actively constitute or produce place' $(2010,884$, emphasis in original). Referring to Nigel Thrift's Non-Representational Theory, Duff underlines how 'bodies are affected [both] in place... [and] by place', such that 'place always already conjures the lived, felt, and relational experience of a thinking, feeling body/subject' (885). If we refer to Maurice MerleauPonty's idea, there is no existence outside of our existence in space:

Every sensation is spatial... sensory experience as the taking up of a form of existence ... It would be contradictory to say that touch is without spatiality, and it is a priori impossible to touch without touching in space since our experience is the experience of a world ... each sensation gives us a particular manner of being in space and, in a certain sense, of creating space. (MerleauPonty 2012 [1962], 230)

Whereas for Duff (referring to de Certeau) space is made through practice, for Merleau-Ponty it is our sensuous experiences of the world that lead us to 'create space'. Merleau-Ponty's understanding of the body as giving access to the social world through sense experiences enables us to 
consider how affects, that is, physical sensations towards another body that accumulate as ways of being in the world, are produced in space and in turn produce space.

Through the concept of power-geometry discussed earlier, Massey suggests that it is not only access to economical and transport resources that affects our experience of space but also social relations, which convert spaces themselves into sites of meaning and power (1994, 146-156). Although Massey situates the complexities of spatial experiences within social interactions determined by power rather than in affects, her text nonetheless suggests the affectivity of spatial existence: 'women's mobility, for instance, is restricted - in a thousand different ways, from physical violence to being ogled at or made to feel quite simply "out of place" - not by “capital”, but by men' (1994, 148, emphasis mine). Both direct physical contact and mediated (such as filmic) experiences certainly affect us physically and therefore condition our reactions, behaviour, habitation of space, and indeed our whole social existence.

For instance, when I walk alone in the city (especially one unknown to me, and at night time), it is how I have been affected personally and collectively (as a woman) and how these affections have also been culturally mediated to me (through films for example) that orient the way I inhabit urban spaces: with fear, distrust, and a general feeling of being out of place. The many online and offline feminist movements against harassment in the post-2000s-such as Stop Street Harassment, the Slut Walks across the globe, the French Ni Pute Ni Soumise, Reclaim the Night, the Everyday Sexism Project, and the \#metoo movement and its French equivalent \#BalanceTonPorc-in fact reveal the collective, institutionalised, and ubiquitous dimensions of sexism and misogyny that negatively affect women's habitation of so-called 'public' spaces. Many women around the world have used their digital cameras to document sexual assaults and the many obstacles women have to overcome in the streets or before they go out of the house, such as in Brussels through "Femmes de la rue" (Peeters 2012), "10 Hours of Walking in NYC as a Woman" (Rob Bliss Creative 2014), and in Cairo, "Creepers on the Bridge" (Loon and Ghunim 2014). On the one hand, the digital sphere overflows with platforms that gather women's testimonies of being harassed, not feeling welcome, or not being accommodated in the urban space-thereby focusing on the negative affects of power-geometries. On the other hand, a plenitude of digital artists denounce what has come to be known as 'rape culture' in an array of creative and affirmative ways. 
These range from comics to photography projects, creative essays, and social media posts, such as 'Projet Crocodiles' (Boutant and Mathieu 2013), 'Sexual Harassment in the Subway of Paris' on Eros-Sana.com (Sana 2015), 'Except, All of Us: Women and the Myth of Safety' (Foreman and Wong 2016), and a recent viral Twitter post that asks women, 'What would you do if all men had a 9pm curfew?' (Muscato 2018), which garnered thousands of answers from women who said they would take walk in parks without fear and with music on, leave their windows open at night, and enjoy doing activities alone. Instead of lamenting the limitations upon women, I argue that these creative instances affirmatively produce forces of potential change, open up a relational dialogue, and give us hope that things could be otherwise.

As Massey's work makes clear, the perception, practice, and production of space, and hence power-geometries, are contingent on a variety of social and cultural factors, and cinema certainly figures as a source of mediated experiences that affect in one way or another our view of the world. For film phenomenologists Vivian Sobchack and Jennifer Barker, films create a 'habitable world ... a space that is deep and textural, that can be materially inhabited' (Sobchack 2004, 151). Barker affirms that attention to texture, space, and rhythm allows us to determine 'the fleshy, muscular, and visceral engagement that occurs between films' and viewers' bodies' (2009, 4). For Barker, the transformative power of cinema lies in these affective exchanges between the film and the spectator. Rather than posit a direct (affective) transmission between film and viewers, I concur with film theorist and phenomenologist Kristin Lené Hole's idea that cinema makes us think about the world differently:

[Cinema] fine-tunes our ethical sensibility with repercussions beyond the cinema doors. Cinema can alter our way of seeing and being in the world. Watching can be a kind of ethical training. Unfortunately, our codified ways of viewing tend to shut down an opportunity to encounter the unmasterable in the world and to see the other, for whom we are responsible, in all her singularity, surprise and wonder. (Hole 2016, 30)

Films force us to see differently and approach the world with wonder and desire. For Kristin Lené Hole in her book Towards a Feminist Cinematic Ethics, the emancipatory character of art lies in its interruption into the illusion of an objective knowledge. Cinema brings our senses to take different directions and constantly re-orientates ourselves, as it shows the world's ever-altering and dynamic existence (Hole 2016, 19). 
My idea of affirmative aesthetics shares Hole's feminist ethics, as demonstrated in her exploration of Claire Denis' films, which she suggests are expressive of the idea that the world and the subject always exist in absolute alterity. As Hole writes, Denis' films 'both visually [register] "difference" or the classifications of gender and race that we use to understand the world, while also emptying them of their assumed or expected content' $(2016,9)$. Similarly, affirmative aesthetics refuse inadequate categories to make sense of the world and of spatial habitation, and thus interrupt totalising ideas of space and subject identity. As we will see, the affirmative films of this book both formulate a diegetic critique of how gender, sexual, and racial categories affect the characters' habitation of space and aesthetically dismantle or suspend the usefulness and inhabitability of these same categories.

An affirmative critique of films starts with the feminist consideration that cinema is an artistic practice that has the potential for emancipation, creation of the new, and raise possibilities that the status quo (reflected through realist narratives) obscures. Sometimes, by walking new paths and taking directions that are unexpected, wilful women characters transform the spaces they inhabit on screen, modifying-within the diegesis-the power-geometries of streets, houses, and cars, and they somehow build spaces that accommodate them. In other occasions, when characters may not appear to transform the structures of power that negatively affect their spatial habitation, the mise-en-scène, sound, montage, and rhythm of the film may soak the screen space with affirmative imaginaries that may be seen through the work of spectatorship. While philosopher Gaston Bachelard brings phenomenological attention to the possible exchanges between the poems' and readers' bodies, his topoanalysis emphasises the affective dimension of poetic images and their potential to produce the new. Bachelard explains that the affectivity of the poetic image arises in the unexpected character of a new image-in its creation of movements, 'spaces of language', and intimacies that carry the imagination along $(1961,8)$. If filmic images are always embedded within a collection of past images (the history of cinema), their particular aesthetic gives shape to different affects and constitutes its potential for expressing the new. In their book The Forms of Films (2004), Leo Bersani and Ulysse Dutoit emphasise that a major virtue of the visual arts is their capacity to make the invisible visible' $(2004,8)$. In order to see what visual arts make visible, however, Bersani and Dutoit suggest that it is necessary to read for forms 
and aesthetic choices rather than characters, which often take central stage. This may unveil 'what is en-deça ... an invisible non-event, which, however, we can, with some effort, see. That effort is the work of spectatorship' (Bersani and Dutoit 2004, 8). What matters, then, is looking for the invisible, that which is en-deça, that which comes to the side or 'before' the sanctioned individualities that cinema tends to make the most visible (and sometimes unforgettable, as the film star is the ultimate example of 'a sharply individualised presence') (8):

We cannot become permanent works of art; the aesthetic subject is not a monumentalising of the self, but rather should be thought as a renewable retreat from the seriousness of stable identities and settled being. (9)

Looking for films' affirmative aesthetics is looking for the absolute alterity of bodies and spaces on screen, that which unsettles categories and our visual habits. A microanalysis of space and bodies on screen may thus reveal an affirmative potential that a strict analysis of characters, narrative, and dialogue may bury.

\section{Filmic Affects as Affirmative Aesthetics}

In both cinema and film theory, the dichotomous and hierarchical gendering of women's and men's bodies manifests as the first dimension that conditions mobility and spatial imaginaries. The fluid approach to space I explore above is designed to accommodate a different perspective on gender on screen. Given my focus upon women characters and their mobility, some kind of review of literature upon these topics might be expected. Yet feminist film theory is lacking an affirmative approach in this respect. In her essay 'Visual pleasure and narrative cinema', Laura Mulvey divides up cinematic spaces (1975): The woman's space is 'flat', she appears on screen, fetishised as an object of the male gaze (by the spectator and the character on screen), her 'beauty ... and the screen space coalesce; she is ... a product ... whose body [is] stylised and fragmented by close-ups... [at once] the content of the film and the recipient of the spectator's look' $(1975,14)$. By contrast, men are given a three-dimensional space, a seat as spectator, and the 'illusion of natural space', as 'the limits of the screen space' are blurred between the male spectator who through the male character can '[gain] control and possession of the woman within the diegesis' 
(Mulvey 1975, 13). In spite of Mulvey's undeniable contribution to film theory, such an approach to representation through Lacan's psychoanalytic theories situates cinema as a mirror of a binary reality and the woman's body as a castrated version of the male's, which does not leave room for transformation. It ultimately reinforces men's spatial control and women's immobility within seemingly fixed and gendered socio-spatial binaries. This draws an opposition between subjects and objects of the gaze, the space on screen and the natural environment, and female characters and male spectators. This vision also focuses on the negative affects of deterministic heteronormative ecologies of cinematic desire.

While numerous film theorists have formulated the same concern, they often come short of answers. Both in cinema and in film theory, I have come across models that lament women's oppression and lack of freedom of movement (Bovenschen 1977; De Lauretis 1984; Irigaray 1977; Johnston 2000 [1973]; Mulvey 1975; Pidduck 1997, 1998), and very few that went beyond that lamentation. In order to take women away from their flat image and replace them in a material world that is perceived, sensed, and lived, many feminist film theorists have attempted to challenge the patriarchy of cinema by developing the idea of a possible 'feminine aesthetics' or a feminine 'language'. When Silvia Bovenschen discusses, a few years later, the idea of a 'feminine aesthetic', she simultaneously refers to a mode of sensory perception and a 'movement by women for women'; that is, an 'art with feminist intentions' (1977, 136). Bovenschen thus promotes a feminist and feminine aesthetic that would free women's imagination while resisting 'all the weeping and wailing' over the oppression of women (111). Echoing Bovenschen's call, Sue Thornham asks whether being the hero of a film's story empowers women and contributes to their unthinking themselves as victims. Like Teresa De Lauretis, Julianne Pidduck, and Natalie Fullwood, Sue Thornham dedicates her work to women and space on screen and warns us of the spaces that contain women. She warns us that post-feminist representations in particular, which Hilary Radner also explores, tend to replace women's quests, albeit heroic, within normative models of femininity $(2012,2-4)$.

In feminist theory and film theory, and in particular the writings of Bovenschen, Claire Johnston (1973), Luce Irigaray (1977), and Lucy Bolton (2011), there is an idea that women need to bond: collectively create narratives that place them into language from which they have been left out, so as to invent their own ('feminine') language. These considerations imply that women would have a particular way of being in the world compared to men; according to Irigaray, a way that is more centred on 
touch as opposed to vision (1977). This separates women and men in two opposed spaces. Instead, as I have discussed, I consider space and spatial habitation as affective, fluctuating with social relations and dynamics of power, which change with affects between bodies. Intervening in this lineage, affirmative politics 'aims at keeping life immanent, nonunitary' in Rosi Braidotti’s words:

This requires a double shift. Firstly, the affect itself moves from the frozen or reactive effect of pain to proactive affirmation of its generative potential. Secondly, this line of questioning also shifts from the quest for the origin or source to a process of elaboration of [ethical] questions that express and enhance a subject's capacity to achieve freedom through the understanding of its limits. (2011a, 294)

By 'mobilising resources that have been left untapped, including our desires and imagination', Braidotti emphasises how political and ethical agency become 'affirmative and geared to creating possible futures [instead of] ... oppositional and tied to the present by negation' (286). Similarly, rather than portraying gendered bodies as negatively affected by the patriarchal construction of space, I argue that films become affirmative when they imagine wilful bodies inhabiting fluid spaces and subject identities.

\section{Wilfulness and Affirmative Politics}

Referring to Foucault, Braidotti writes that 'the material that damages is also that which engenders positive resistance, counteraction, or transcendence' (201la, 285). The idea that being negatively affected 'engenders positive resistance' strongly echoes Sara Ahmed's concept of wilfulness, which the preface of this book introduced. As Ahmed underlines, 'willing is a matter of how we are affected' $(2014,76)$. Because of the negative affects produced by gendered restrictions on their mobility, the protagonists of my chosen films act according to these principles (although wilfulness is an affective experience rather than a conscious decision). As well as the models of 'dangerous women' and/or 'lost' wandering women that road movies epitomise (as the following chapter will show), we can find wilful women who refuse to be 'straightened out', to be put back on the right path of happiness (as Sara Ahmed would put it). In a certain way, they find what Lauren Berlant calls 'adjustments' to not reaching the neoliberal fantasies of 'the good life', much like the characters in the films $\mathrm{La}$ Promesse (1996) and Rosetta (1999) by the Dardenne brothers (Berlant 
2011, 2-3). Reading Ahmed reminds me of a series of filmic characters: wilful wandering women demanding spatial power, such as the iconic Thelma and Louise, Wanda in the film of the same name (Barbara Loden 2006 [1970]), Anna in Les rendez-vous d'Anna (Chantal Akerman 1978), Jeanne and Marie in Messidor (Tanner 1995 [1979]), Helene in Germany, Pale Mother (Helma Sanders-Brahms 2008 [1980]), Rosaleen in The Company of Wolves (Neil Jordan 2002 [1984]), Mona in Sans toit ni loi (Agnès Varda 1985), Radha in Fire (Deepa Mehta 1996), Have, Ahoo, and Hoora in The Day I Became a Woman (Marzieh Meshkini 2000), Cathy Whitaker in Far from Heaven (Todd Haynes 2002), the women of The circle (Jafar Panahi 2000) and Offside (Panahi 2006), Munis, Faezeh, Farrokhlagha in Women Without Men (Shirin Neshat 2009), and the three female protagonists of 678 (Mohamed Diab 2010), among many others. These wilful wanderers persist in inhabiting the street space, even as they recognise it as being a male arena that does not accommodate them.

While Braidotti calls for the endurance of the subject, who is '[pointing] to the struggle to sustain the pain without being annihilated by it' (2011b, 289), Sara Ahmed asserts that 'wilfulness involves persistence' $(2014,2)$. Ahmed underlines the difficulties in wilful persistence, as seen in many 'female road movies' and in a majority of the films mentioned above. It is often easier to obey than to disobey, such that 'a subject can be willing [to obey] in order to avoid being forced' (139). Just as 'persistence can be an act of disobedience', wilfulness tends to be perceived as a problem, of someone who wills too much or wills wrongly (Ahmed 2014, 2). As I will explore in my analysis of Messidor in the next chapter, it is by persistently inhabiting a space dominated by men to which they do not belong that Jeanne and Marie are identified as willing too much or willing wrongly, and are portrayed as 'dangerous women'. In road movies, it seems that it is the wandering of 'unaccompanied' female bodies that is identified as a danger for patriarchy and thus needs to be annihilated within the narrative. In order to extract the affirmative politics of films that portray women's wilfulness instead of their alienation, we must look for a new vocabulary, one that recognises wilfulness as affirmative spatial habitation and social existence.

In their theories both Braidotti and Ahmed underline the importance of generational lines and spatial movement. While Braidotti places emphasis on the activity of 'a group project that connects active, conscious, and desiring citizens... and [constructs] social horizons of hope' (201la, 294-95), ${ }^{17}$ Ahmed insists on the importance of creating new wilful paths 
for women to follow. The wilful subjects creating these paths may already be following others before them $(2014,153-54)$. Both Braidotti and Ahmed appear to situate affirmative politics and wilfulness, respectively, within space: both practices require the spatial movement of one group or individual and their 'democratic' access to the public sphere (see Sheller and Urry 2000).

Ahmed develops her concept of wilfulness across two books, The Promise of Happiness (2010) and Willful Subjects (2014), which both rely on her first book The Cultural Politics of Emotion (Ahmed 2004). Ahmed often describes wilful subjects as wanderers '[straying] from official paths, [creating] desire lines' that they hope others will follow $(2014,21)$. Following Ahmed's work in her book Queer Phenomenology, wilful subjects may be 'disorientated', attempting to orient themselves on a different path than the one prescribed for them; in this sense, wilful subjects queer expected lines. Looking at travelling women in the road movie, we find wandering women, not on a journey of self-transformation, like male protagonists, but in a sphere that is not theirs and in which they struggle to exist. They are not 'naturally' accommodated by the public sphere, as men are; instead, they struggle to move around and lack hope of finding an answer or destination through their movement, as men usually do.

The women protagonists of Messidor, Head-On, Wadjda, and Vendredi soir - the films I analyse in this book-inhabit space in a wilful way and from an affirmative position. The three protagonists also engage in processes of transformation of the power-geometries that subjugate them. They experience wilfulness to create different paths for themselves and other women to follow, while already following paths of women before them. Instead of the patriarchal binaries of realist films bounded by the present space-time, these films express the wilfulness of their female characters through affective forms, giving shape to an aesthetics of affirmation. From one generation to the next, and from one culture to another, the wilful paths of women on screen open up possibilities, transforming spatial imaginaries and ultimately perhaps spaces themselves.

Much like Braidotti's call for affirmative politics, Ahmed's concept of wilfulness implies that the negativity of one's affective position is transformed into a productive, affirmative force. For Ahmed, wilfulness emerges as a political act, in which wilful subjects are happy to cause trouble, happy to 'be the cause of unhappiness' (Ahmed 2010, 15). As they become identified as 'feminist killjoys', the protagonists of the films in this book (Jeanne and Marie, Laure, Wadjda, and Sibel) manifest, in Ahmed's words, as 'wilful women, unwilling to get along, unwilling to preserve an idea of 
happiness' $(2014,2)$. As wilful subjects, they refuse to follow the path they are asked to follow in a sexist and patriarchal society, they have the will to 'not to go with the flow', and they will 'what is not present' as they march 'with angry feet' and 'put their bodies in the way' of patriarchal imaginaries (Ahmed 2014, 11; 8; 163). As such, wilfulness involves spatial movements and 'full', lived, embodied habitation of one's space. It is through aesthetic choices (mise-en-scène, sound, cinematography) that the films give shape to space and to the protagonists' empowered habitation of these spaces.

Ahmed defines becoming wilful as being involved in an affective project, a project to overcome an obstacle that we encounter, to reach for what seems out of reach $(37 ; 41)$. Like Braidotti's affirmative project, the wilful project is oriented towards 'objects of hope': founding alternative paths, opening up possibilities and imagination, and finding 'space to breathe'be it as a person of colour in a racist world or as a woman in a misogynistic world (Ahmed 2010, 120). In both Braidotti's and Ahmed's work, and as for Spinoza, Massumi, and Deleuze, imagination appears as a source for transformation. Desire and imagination manifest as 'resources that have been left untapped' and have the potential to 'create possible worlds' (201la, 286), or to reach for what seems out of reach, to reach for the virtual within the real.

Both Ahmed's wilfulness and Braidotti's affirmative politics advocate in a very similar fashion (albeit without acknowledging each other) the production of (positive) resistance to the injustices of the present through the transformation of negative affects into wilful or affirmative forces. While wilfulness tends to the actions (affective, unconscious) of characters, affirmative refers to the forms of the film: its aesthetic production of spaces and bodies that escape or suspend fixed ideas of gender and powergeometries. The films chosen bring women's 'mobility' under an 'affirmative' light, by portraying their wilful bodies' habitation of space-time in continual transformation. When Braidotti writes her 'Plea for affirmative ethics', she calls for affirmative critical thinking and activism which understands humanity as not rising from freedom, 'but rather that freedom is extracted out of the awareness of our multiple limitations ... affirmation [being] about freedom from the burden of negativity, through the understanding of these limitations' (2011b, 269).

It is due to the limitations on their 'freedom' within the patriarchal status quo that the protagonists of Messidor, Vendredi soir, Wadjda, and Head-On experience wilfulness. It is also through each film's understanding of the 
patriarchal limitations on space and mobility for women that their cinematic spaces become 'spaces of wilfulness', spaces that the women protagonists fully inhabit. Similarly, albeit in different measures and forms, if one looks beyond representation, the filmic aesthetics of Sans toit ni loi, Marseilles, Les rendez-vous d'Anna, 678, Ten, and The Day I Became a Woman, among others, may appear to share similarities with the films analysed here, as they affirmatively transform the gendering of space through the 'wilful wandering' of their women subjects. I argue that the films' affirmative images of spatial habitation and 'mobility' perform a 'remapping of dwelling', as Giuliana Bruno suggests: re-writing streets, cars, and houses as ever-changing space-time, lived, experienced, and inhabited affectively.

\section{Book Structure}

My quest for affirmative aesthetics explores how cinematic representations of specific diegetic spaces contribute to the disentanglement of space from seemingly fixed and determined power-geometries on screen. I am looking for forms, light, textures, rhythms, and sound that give shape to affirmative affects: cinematic aesthetics that counteract the established relations between subject, gender, and space. The affirmative aesthetics of film include both wilful women characters, which inhabit space against normative flows, and aesthetic choices (rhythm, colours, mise-en-scène, cinematography, sound) that unveil spaces and bodies as fluid and unbounded. As the films' aesthetics produce specific affects, they also create narrative content and convey sociocultural meanings. More than 'positive representations of women doing positive things', I refer to affirmative aesthetics as feminist works that dismantle binaries and give form to fluid genders, spaces, and identities. A micro-analysis of cinematic spaces and characters' relations to space reveals the affirmative aesthetics of films such as Messidor and Head-On (in Chaps. 2 and 5), which may otherwise remain buried in negativity. Although in appearance these films may seem to focus overtly on how the power-geometries of streets and other 'public' spaces negatively affect women, they aesthetically give form to micro-instances of affirmation wilful women that inhabit space 'freely' - and spaces that offer new configurations. While not all feminist works can be deemed affirmative, the affirmative aesthetics of films is a spectrum rather than a binary division. This book also hopes to open the reflection towards an affirmative form of critique, one that critically reads for forms that establish subjects and space as fluid, relational, and in constant transformation. Affirmative 
Aesthetics shows how this happens in spite of the negativity and apparent fixity that may characterise realist narratives.

Women's wilful habitation of space takes various forms that are worth exploring. The films of this book, from a diversity of cultural contexts, in fact engage with very different cultural forms of patriarchy. While the concepts of mobility, space, and gender adopt distinct shades, they each speak affectively to women's spatialities. In his work on imagination as a social practice, Appadurai celebrates the cross-cultural aspect of imagination 'for the creation of multiple horizons of possibility' $(2002,34)$. As the book looks for models of films that situate spatial habitation within fluid-unbounded-social and affective relations, it looks at a cross-cultural corpus of films so as to broaden the diversity and plurality of aesthetic 'acts of resistance' and of 'margins of manoeuvrability' (echoing Massumi's words, 2002, 3). The four films chosen are case studies of affirmative aesthetics: filmic transformation of gendered spatial imaginaries. The films give different aesthetic forms to spaces, identities, and the wilfulness of their women characters: Messidor, a wandering without goal, a pause for reflection, allows to unravel the problematic gendering of the notion of 'mobility' in film; Vendredi soir deepens the idea of inhabiting space as empowering through a haptic aesthetic that converts bodies into lived bodies, focuses on sensations and textures, and brings in the imaginative; Wadjda reveals the necessity for women to find their own space, and to sometimes put on a mask so as not to be identified as wilful; Head-On pushes the idea of masquerade and performance of gender to abjection, an erotic connection to one's bodily environment as an escape from norms and expectations.

The interdisciplinary models explored thus far go far beyond the critical theories that maintain men and women within gendered narratives of travel and mobility. By including feminist geography, feminism and gender theories, and theories of affect and phenomenology within film theory, this book considers spatial habitation as fluid and dynamic rather than 'static'. It posits women's subjectivities as bodily situations and spatial experiences, and extends beyond the 'grand (male) narratives' of travel by expanding representational analysis into an analysis of the forms of wilful affects and an affirmative rewriting of space, power, and bodies. Chapter 2 shows the limits of considering the mobility of women in the same terms as men's and reveals the need for other tools and vocabulary to consider women's relations to space. Through the close analysis of Messidor (Alain Tanner 1979), the chapter explores how the (male-dominated) road movie's conventional 
representation of mobility as transformative and as a repossession of the known (home, as domesticated space) does not work for women. Because of the obstacles women need to overcome before even leaving home, the transformative forces that generally emerge from the road movie genre through movement emerge here through the wilfulness to keep moving without aim and with the ability to pause, reflect, and inhabit space through lived affective experiences. The subversion of the genre creates affects of hope through inhabiting instead of travelling. The mise-en-scène of the film, with scenes often starting in media res, emphasises Jeanne and Marie's will to not stop moving: empowerment is about becoming mobile and embracing the road. If Messidor seems to critically condemn women characters to immobility, a micro-analysis of bodies and cinematic space reveals the film's affirmative aesthetic in face of the negativity present within the diegesis.

The following three chapters, which analyse Vendredi soir, Wadjda, and Head-On, are divided between the particular consideration of a space-time affected by the 'patriarchal gendering of space', namely the car, the house, and the street, respectively (as we will see, the habitation of these spaces prove to be intimately interrelated). These three films have in common the absence of a space that can be called 'home', and the difficulties that women face when roaming the streets (as observed in Messidor). Vehicles lose their aspect of possession of the land they travel through and instead enable women to fully inhabit spaces of intimacy (spaces of their own and of contact with others). In addition, 'home' becomes a liminal space that disrupts private/public boundaries, and the street is a space that one affectively embodies.

The third chapter, which analyses Claire Denis' film Vendredi soir (2002), delves deeper into the idea that affirmative aesthetics takes shape through micro-relations between bodies and space. The chapter anchors wilfulness into the lived habitation of space and the forming of a 'lived body' on screen. In the film, the car loses its dimension of travel and appraisal of the other through the windscreen and becomes a space of intimacy for the characters, a space in which the affectivity (the bodily experiences) of space manifests narratively and aesthetically. Whereas Sibel and Wadjda are overtly wilful within the narratives of Head-On and Wadjda, respectively, Laure, the woman protagonist of Vendredi soir, manifests as a timid woman inhabiting space through integrated gendered 
norms. Three aspects of the film's aesthetic, which become especially apparent when going beyond representational analysis, transform the negative affects of Laure's gendered situation into affirmative habitation of space. First, the magical aesthetic of the film creates a sensuous experience of the city, blurring the boundaries that separate diegetic 'real' from subjective imaginaries and allowing the 'virtual possibilities of the real' (in Deleuze's terms) to be actualised on screen. Second, through a haptic aesthetic that merges the bodies of the male and female protagonists, Denis blurs the gendered bodily binaries that regulate spatial habitation, as seen in the previous chapter. Finally, the film 'frees' space of its negative affects by building up 'spaces of intimacy' through representational and affective images, liminal spaces of encounter that (temporarily) suspend the patriarchal gendering of space. The film's blurring of the binary categories real/imaginary, male/female, and public/private becomes apparent through the analysis of bodies' micro-relations to space. The film's aesthetic creates an affirmative passage between virtual and actual, which counteracts the negative affects of power-geometries on women's habitation of space, and creates a transition to becoming a lived desiring body.

Chapter 4 reads for wilfulness as filmic forms in Haifaa Al-Mansour's Wadjda (2012) and shows how affirmative ethics is about understanding the limitations to our freedom. When the young protagonist Wadjda realises that she cannot have a bicycle because she is a girl, she begins to confront the unequal and gendered practices of space. As Wadjda claims 'what is simply given to others' (echoing here Sara Ahmed 2014, 147), her wilfulness to create an alternative future translates on screen as micro-instances of activism. If in cinema the traveller often takes central stage, the one who stays, like Wadjda, may also inhabit space in wilful ways and modify the power-geometries of space. As the chapter adopts the tools of phenomenology and explores how Wadjda and her mother inhabit different places, such as the street, the school, and the house, it shows how objects mediate wilfulness. Doors, veils, phones, and bicycles all produce wilful forms and make space for the protagonists to refuse docility. The recognition of one's limitations and the necessary masking of wilfulness take spatial shape; the roof of the house as such becomes a 'heterotopic' space (Foucault 2004 [1984]), at once contained within and opening beyond the structures of patriarchy-it is simultaneously a space subjected to unequal powergeometries and an affirmative space that accommodates and fosters wilfulness. 
Chapter 5 focuses on the street as a contested diegetic space in Fatih Akin's film Gegen die wand/Head-On (2004), one that is gendered and requires negotiation. While the performance of gender appears as a spiral from which one cannot escape, it also appears as a means to disrupt established roles and the myth of subject identities governed by gender and racial categories. This chapter takes as point of departure Judith Butler's idea that gender is always a performance insofar as it figures as ideals that are uninbabitable (1993). It also follows Audre Lorde's idea of connecting to the erotic within one's body as a feminist approach to refuse conventions and require the best for oneself (1984). By examining the woman protagonist Sibel's body movements on screen (see also Kate Ince's phenomenological approach to film 2017), the chapter shows how dancing, walking in the streets, connecting to the erotic and abjecting one's body take affirmative forms; a suspension of the gendering and racialisation of space. While Sibel is punished for taking ownership of her body and sexuality several times in the diegesis, the affirmative aesthetic of the film becomes clear through her embodied habitation of everyday spaces as spheres of the possible.

In one way or another, Messidor, Vendredi soir, Wadjda, and Head-On engage in a process of transformation of space and of the affects of spatial habitation. While the films' narratives may (more or less overtly) confront and oppose the patriarchal gendering of space, it is their filmic aesthetics that transform negativity into affirmative forces. Desire manifests in different forms in each film, as lived, wilful, masquerading, and erotic bodies. The desiring bodies of the protagonists and of the films themselves experience a will to find and create spaces of intimacy, spaces of belonging, belonging then not to the current dichotomous conceptions of space but rather to affirmative fluid spaces.

While my approach, just as Braidotti's, is relational and geared towards alternative possibilities, it is anchored in visual culture and in finding concrete models of representation and affective forms that refuse to situate gender, sexuality, or race as valid categories of subject identities and spatial habitation. The affirmative in my view is a radical shift from binary models to recognising the deeply relational and complex dimension of existence. Rather than producing positive or negative affects, Affirmative Aesthetics: and Wilful Women modifies the reading of space and bodies as necessarily gendered, as found in the road movie genre or in numbers of films seen 
through the lens of feminist film theory. In this sense, the book follows the disobedience and disorientating dimension of Sara Ahmed's Queer Phenomenology (2006) and Willful Subjects (2014), the interruptions of the myth of the subject in Kristin Lené Hole's Towards a Feminist Cinematic Aesthetic (2016), and the radical ideality of José Esteban Muñoz's Cruising Utopia (2009). Unbalanced power-geometries spur a resistance that is collective and affective, an affirmative resistance that I argue manifests on screen as filmic forms that need to be read for.

\section{Notes}

1. As we will see throughout this book, though in road movies straying (female) wanderers are opposed to extensive (male) travellers, as the second chapter will explore, wandering off the prescribed path and inhabiting space without extensive movement become forms of affirmation of one's wilfulness.

2. Tanu Priya Uteng and Tim Cresswell observe how 'scientific schoolbooks [describe] the human reproductive process' in terms of the passive egg and the travelling sperm, and how touristic mobilities are still anchored in the masculinist concept of travel as 'exploration and conquest' (2008, 2-4). As they hope to depart from dichotomous gendered oppositions, Uteng and Cresswell advocate considering 'mobilities more generally' in a wider context and emerging from 'a variety of disciplinary backgrounds' to consider mobility through non-binary aspects: as at once 'physical movements', 'meanings associated with movement', and practice, 'embodied and experienced aspects of moving' (6).

3. Working-class women and prostitutes already had access to the public space, but were categorised as 'non-respectable'.

4. See also Specters of Marx: the State of the Debt, the Work of Mourning, and the New International (Jacques Derrida 1993).

5. In fact, Wilson underlines the alienation of the male flaneur in the city, 'who represented not the triumph of masculine power, but its attenuation', a haunting figure, 'sexually insecure' and 'annihilated' by the anonymity of the urbanisation of the metropolis (Wilson 2001, 86-88). Walter Benjamin also emphasises that by roaming in the arcades filled with commodities 'arousing desires', the male flàneur too was part of the consumer mass $(1999,42)$. He was gazing at the world around him and was consuming its images as commodities, converting women themselves into commodities of his gaze and artistic production. In Benjamin's Marxist reading of the flaneur figure, not only is he a consumer but also a commodity of the capitalist society, whereby his strolls in the city were his necessary labour time for his artistic production $(1999,446-448)$. In this sense, the com- 
modification and consumption to which the city appealed negatively affected both the flâneur and the flâneuse. However, if Baudelaire compared poets to prostitutes selling themselves through their art, female prostitutes had a much harder time for they had to be subjected to intimate medical controls and had increasingly been marginalised from other women.

6. Braidotti's 'cartography' resonates with Giuliana Bruno's idea of the map (in Atlas of emotion, 2002) and Moira Gatens' imaginaries (see Imaginary bodies: Ethics, power and corporeality, 1996), as I will explain later in this chapter. In fact, Bruno writes about film as 'a modern cartography: its haptic way of site-seeing turns pictures into architecture, transforming them into a geography of lived, and living, space' $(2002,9)$.

7. Before the rise of feminist geography at the beginning of the 1990s, in the writings of Doreen Massey, Gillian Rose, Linda McDowell, and Daphne Spain women's bodies had thus far been paired with childbirth, mothering, nurturing, and nature, and conflated with the domestic sphere, unproblematically shaping and legitimating gender roles and power relations. Gillian Rose explains that 'socially constituted relations and identities' have indeed become naturalised for claiming their source in the body (1993, 30). Rose describes how the public sphere became constructed around notions of 'rationality, individuality [and] self-control' associated with the 'masculine' standing in opposition to the female body and its naturalised 'interpersonal inclination' $(35 ; 26)$.

8. In his book on gendered urban spatialities, Les murs invisibles, social geographer Guy Di Méo argues that queering our notions of space and gender is essential to reach an equal sense of spatial habitation in the city (2011, 317). Using Lefebvre's concept of the triplicity of space (lived-perceivedconceived), Di Méo interprets gender and space as evolutive processes, constituted by social behaviours and situations (313-314).

9. See the review articles by Kristyn Gorton (2007) and Pedwell and Whitehead (2012) for comparative accounts of affect theory from feminist perspectives.

10. Nigel Thrift similarly understands affect as a 'form of [indirect and nonreflective] thinking ... [an] intelligence about the world' (175), 'transhuman ... understood as effects of the events to which their body parts (broadly understood) respond and in which they participate' $(2008,175)$.

11. Translation mine. 'L'affect (affectus) 'c'est la variation continue de la force $\mathrm{d}$ 'exister [ou de la puissance d'agir] de quelqu'un, en tant que cette variation est déterminée par les idées qu'il a' (Deleuze 1978-1981, 9).

12. Spinoza writes that 'the mind, as far as it can, endeavours to imagine whatever increases or assists the body's power of activity, that is those things it loves' (116), whereby love (as opposed to hate) is 'merely pleasure accompanied by the idea of an external cause' (113) and pleasure (as opposed to pain) is 'the passive transition of the mind to a state of greater perfection' 
(1982 [1677], 111). For Spinoza, imagination leads the subject to attribute elements of pain or pleasure to an object (present or imagined) that they have previously regarded with love or hate (115-16), thereby the body can be affected by the sole imagination of the object. For Spinoza, one's affect constantly varies between two poles, of pleasure and pain, that is the increase or decrease of the power to act, or 'the will to exist' in Deleuze's words (1981).

13. Along the same line as Spinoza referring to the 'ideas of these affections' as fully contingent with affection itself, Margaret Wetherell writes that 'core affects... are simultaneously perceived, organised, categorised, labelled and communicated becoming socially recognisable 'emotions'. Any initial bodily hit, in other words, is always already occurring within an ongoing stream of meaning-making or semiosis' $(2013,355)$.

14. While Ahmed uses the American spelling 'willfulness', which will be preserved when quoting her work, this book uses the British spelling 'wilfulness', for both coherence and integrating the idea that the will does not emanate from an individual subject, but that wilfulness rather figures as collective affect that take shape through filmic forms on screen.

15. Part of 'the whole of matter', each object contains endless virtualities (in Deleuze's words), potentialities that it can become, but it first 'needs to unbecome, undo its actuality as fixed givenness' (Grosz 2005, 10). See also Le Bergsonisme (Deleuze 1966).

16. 'L'affect, c'est la variation continue ou le passage d'un degré de réalité à un autre' (Deleuze 1978-1981, 10).

17. For more on the geographies of hope, see David Harvey's Spaces of hope (2000).

\section{REFERENCES}

Ahmed, Sara. 2004. The Cultural Politics of Emotion. Edinburgh: Edinburgh University Press.

—. 2006. Queer Phenomenology: Orientations, Objects, Others. Durham/ London: Duke University Press.

- 2010. The Promise of Happiness. Durham/London: Duke University Press. 2014. Willful Subjects. Durham: Duke University Press.

Akerman, Chantal. 1978. Les Rendez-Vous d'Anna. DVD. France/Belgium/West Germany: Paradise Films.

Akin, Fatih. 2004. Gegen Die Wand [Head-On]. DVD. Germany/Turkey: Strand Releasing.

Al-Mansour, Haifaa. 2012. Wadjda. DVD. Saudi Arabia/Germany: Sony Pictures Home Entertainment.

Appadurai, Arjun. 2002. The Right to Participate in the Work of the Imagination. In Transurbanism, ed. Arjen Mulder. Rotterdam: NAi Publishers. 
Bachelard, Gaston. 1961. La Poétique de l'espace. lst edition in 1957. Paris: Presses Universitaires de France.

Barker, Jennifer M. 2009. The Tactile Eye: Touch and Cinematic Experience. Berkeley/Los Angeles/London: University of California Press.

Benjamin, Walter. 1999 [1927-1940]. The Arcades Project. Cambridge, MA: Belknap Press.

Berlant, Lauren. 1997. The Queen of America Goes to Washington City: Essays on Sex and Citizenship. Durham: Duke University Press.

Berlant, Lauren Gail. 2011. Cruel Optimism. Durham: Duke University Press.

Bersani, Leo, and Ulysse Dutoit. 2004. Forms of Being: Cinema, Aesthetics, Subjectivity. London: BFI Publishing.

Bolton, Lucy. 2011. Film and Female Consciousness: Irigaray, Cinema and Thinking Women. Hampshire/New York: Palgrave Macmillan.

Boutant, Juliette, and Thomas Mathieu. 2013. Projet Crocodiles. Comics Online. https://projetcrocodiles.tumblr.com

Bovenschen, Silvia. 1977. Is There a Feminine Aesthetic? New German Critique 10: 111-137.

Braidotti, Rosi. 201la. Nomadic Theory: The Portable Rosi Braidotti. Chichester: Columbia University Press.

- 2011b. The New Activism: A Plea for Affirmative Ethics. In Art and Activism in the Age of Globalization, ed. L. De Cauter, R. De Roo, and K. Vanhaesebrouk, 264-270. Rotterdam: NAi Publishers.

Brennan, Teresa. 2004. Transmission of Affect. London: Continuum.

Brinkema, Eugenie. 2014. The Forms of the Affects. Durham/London: Duke University Press.

Bruno, Giuliana. 2002. Atlas of emotion: Journeys in art, architecture, and film. London/New York: Verso Books.

Butler, Judith. 1993. Critically Queer. GLQ: A Journal of Lesbian and Gay Studies $1(1): 17-32$.

1997. Excitable Speech: A Politics of the Performative. New York: Routledge.

Colebrook, Claire. 2000. From Radical Representations to Corporeal Becomings: The Feminist Philosophy of Lloyd, Grosz and Gatens. Hypatia 15 (2): 76.

Cresswell, Tim. 2000. Falling Down: Resistance as Diagnostic. In Entanglements of Power: Geographies of Domination/Resistance, ed. Joanne P. Sharp, Paul Routledge, Chris Philo, and Ronan Paddison, 256-268. London/New York: Routledge.

de Certeau, Michel. 1984. The Practice of Everyday Life. Berkeley: University of California Press.

De Lauretis, Teresa. 1984. Alice Doesn't: Feminism, Semiotics, Cinema. Bloomington/Indianapolis: Indiana University Press.

Del Río, Elena. 2008. Deleuze and the Cinemas of Performance: Powers of Affection. Edinburgh: Edinburgh University Press.

Deleuze, Gilles. 1966. Le Bergsonisme. Paris: Presses Universitaires de France. 
1976. Différence et répétition. Paris: Presses Universitaires de France.

1978-1981. Cours Vincennes: Intégralité du cours 1978-1981, cours du 02/12/1977 (Spinoza). Retrieved on 9 Oct 2019 from https://www.webdeleuze.com/textes/188

- 1985. Cinéma 2: L'image-temps. Paris: Editions de minuit.

Denis, Claire. 2002. Vendredi Soir. DVD. France: Bac Films.

Derrida, Jacques. 1993. Spectres de Marx: l'état de la dette, le travail du devil et la nouvelle internationale. Paris: Editions Galilée.

Di Méo, Guy. 2011. Les murs invisibles: femmes, genre et géographie sociale. Paris: Armand Colin.

Diab, Mohamed. 2010. 678. DVD. Egypt: Audio Visual Entertainment.

Duff, Cameron. 2010. On the Role of Affect and Practice in the Production of Place. Environment and Planning D: Society and Space 28: 881-895.

Dyer, Richard. 2002 [1992]. Only Entertainment. London/New York: Routledge. Fanon, Frantz. 1967 [1952]. Black Skin, White Masks. New York: Grove Press.

Foreman, Aricka, and Mimi Wong. 2016. Except, all of us: Women and the myth of safety, February 2. Essay Online. Retrieved on 9 Oct. 2019 from https:// theoffingmag.com/enumerate/except-all-of-us

Foucault, Michel. 2004 [1984]. Des espaces autres. Empan 2 (54): 12-19.

Fullwood, Natalie. 2015. Cinema, Gender, and Everyday Space: Comedy, Italian Style. New York: Palgrave Macmillan.

Gorton, Kristyn. 2007. Theorizing Emotion and Affect: Feminist Engagements. Feminist Theory 8 (3): 333-348.

Grosz, Elizabeth. 2005. Bergson, Deleuze and the Becoming of Unbecoming. Parallax 11 (2): 4-13.

Harvey, David. 2000. Spaces of Hope. Edinburgh: Taylor \& Francis.

Haynes, Todd. 2002. Far from Heaven. DVD. USA/France: Focus Features and Vulcan Productions.

Hemmings, Clare. 2005. Invoking Affect. Cultural Studies 19 (5): 548-567.

Hole, Kristin Lené. 2016. Towards a Feminist Cinematic Ethics: Claire Denis, Emmanuel Levinas and Jean-Luc Nancy. Edinburgh: Edinburgh University Press.

hooks, bell. 2009. Belonging: A Culture of Place. New York: Routledge.

Ince, Kate. 2017. The Body and the Screen: Female Subjectivities in Contemporary Women's Cinema. London/Oxford: Bloomsbury.

Irigaray, Luce. 1977. This Sex Which Is Not One [Ce sexe qui n'en est pas un]. Ithaca: Cornell University Press.

Johnston, Claire. 2000 [1973]. Women's Cinema as Counter-Cinema. In Feminism and Film, ed. E. Ann Kaplan, 22-33. Oxford: Oxford University Press.

Jordan, Neil. 2002 [1984]. The Company of Wolves. DVD. United Kingdom: Hen's Tooth Video.

Lefebvre, Henri. 1974. La production de l'espace. Paris: Anthropos. 
Loden, Barbara. 2006 [1970]. Wanda. DVD. USA: Parlour Pictures.

Lorde, Audre. 1984. Sister Outsider: Essays and Speeches. Berkeley: Crossing Press.

Massey, Doreen B. 1994. Space, Place, and Gender. Minneapolis: University of Minnesota Press.

Massey, Doreen. 2000. Entanglements of Power: Reflections. In Entanglements of Power: Geographies of Domination/Resistance, ed. Joanne P. Sharp, Paul Routledge, Chris Philo, and Ronan Paddison, 279-286. London/New York: Routledge.

Massumi, Brian. 2002. Navigating Movements. 21C Magazine 2: 210-243.

McDowell, Linda. 1999. Gender, Identity and Place: Understanding Feminist Geographies. Minneapolis: University of Minnesota Press.

Mehta, Deepa. 1996. Fire. DVD. India/Canada: Seville Pictures.

Merleau-Ponty, Maurice. 2012 [1962]. Phenomenology of Perception. London/ New York: Routledge.

Meshkini, Marzieh. 2000. Roozi ke zan shodam [The Day I Became a Woman]. DVD. Iran: Makhmalbaf Productions.

Mulvey, Laura. 1975. Visual Pleasure and Narrative Cinema. Screen 16 (3): 6-18.

Muñoz, José Esteban. 2009. Cruising Utopia: The Then and There of Queer Futurity. New York: New York University Press.

Muscato, Danielle. 2018. Ladies, What Would You Do if All Men Had a 9pm Curfew?, September 26. Retrieved on 27 Sep 2018 from https://twitter.com/ DanielleMuscato/status/1044686450028163074

Neshat, Shirin. 2009. Zanan-e bedun-e mardan [Women without Men]. DVD. Iran: Essential Filmproduktion.

Panahi, Jafar. 2000. Dayereh [The Circle]. DVD. Iran: Winstar TV and Video.

- 2006. Offside. DVD. Iran: Artificial Eye.

Pedwell, Carolyn, and Anne Whitehead. 2012. Affecting Feminism: Questions of Feeling in Feminist Theory. Feminist Theory 13 (2): 115-129.

Peeters, Sofie. 2012. Femmes de la rue, July 26. Video Online. Retrieved on 3 Mar 2013 from https://www.dailymotion.com/video/x3fb4sp

Pidduck, Julianne. 1997. Travels with Sally Potter's Orlando: Gender, Narrative, Movement. Screen 38 (2): 172-189.

- 1998. Of Windows and Country Walks: Frames of Space and Movement in 1990s Austen Adaptations. Screen 39 (4): 381-400.

Radner, Hilary. 2010. Neo-Feminist Cinema: Girly Films, Chick Flicks, and Consumer Culture. New York: Routledge.

Rob Bliss Creative. 2014. 10 Hours of Walking in NYC as a Woman. YouTube. Posted on 28 Oct 2014. https://youtu.be/blXGPvbWn0A

Rose, G. 1993. Feminism and Geography: The Limits of Geographical Knowledge. Cambridge: Polity Press.

Sana, Eros. 2015. Sexual Harassment in the Subway. Photography Online. http:// eros-sana.com/auteur/france/sexual-harassment 
Sanders-Brahms, Helma. 2008 [1980]. Deutschland Bleiche Mutter [Germany, Pale Mother]. DVD. West Germany: Facets Video.

Sedgwick, Eve Kosofsky. 2003. Touching Feeling: Affect, Pedagogy, Performativity. Durham: Duke University Press.

Sharp, Joanne P., Paul Routledge, Chris Philo, and Ronan Paddison, eds. 2000. Entanglements of Power: Geographies of Domination/Resistance. London/New York: Routledge.

Shaviro, Steven. 2010. Post-cinematic Affect. Winchester/Washington, DC: 0 [zero] Books.

Sheller, Mimi, and John Urry. 2000. The City and the Car. International Journal of Urban and Regional Research 24 (4): 737-757.

Sobchack, Vivian. 1992. The Address of the Eye: A Phenomenology of Film Experience. Princeton: Princeton University Press.

- 2004. Carnal Thoughts: Embodiment and Moving Image Culture. Berkeley/Los Angeles/London: University of California Press.

Solnit, Rebecca. 2001. Wanderlust: A History of Walking. London: Penguin Books. Spain, Daphne. 1992. Gendered Spaces. Chapel Hill: University of North Carolina Press.

Spinoza, Baruch. 1982 [1677]. The Ethics and Selected Letters. Indianapolis/ Cambridge: Hackett.

Stewart, Kathleen. 2007. Ordinary Affects. Durham: Duke University Press.

Tanner, Alain. 1995 [1979]. Messidor. VHS. Switzerland: Citel Films.

Thornham, Sue. 2012. What If I Had Been the Hero?: Investigating Women's Cinema. Basingstoke: Palgrave Macmillan.

- 2019. Spaces of Women's Cinema: Space, Place and Genre in Contemporary Women's Filmmaking. London: The British Film Institute.

Thrift, N.J. 2008. Non-representational Theory: Space, Politics, Affect. New York: Routledge.

Uteng, Tanu Priya, and Tim Cresswell. 2008. Gendered Mobilities. Farnham: Ashgate Publishing.

Loon, Tinne Van, and Colette Ghunim. 2014. Creepers on the Bridge, August 30. Vimeo. Retrieved on 9 Oct 2019 from https://vimeo.com/104798581

Varda, Agnès. 1985. Sans toit ni loi [Vagabond]. VHS. France: Ciné Tamaris.

Wetherell, M. 2013. Affect and Discourse - What's the Problem? From Affect as Excess to Affective/Discursive Practice. Subjectivity 6: 349-368.

Wilson, Elizabeth. 1991. The Sphinx in the City: Urban Life, the Control of Disorder, and Women. Berkeley: University of California Press.

- 2001. The Contradictions of Culture: Cities, Culture, Women. London: SAGE.

Wolff, Janet. 1985. The Invisible flâneuse: Women and the Literature of Modernity. Theory, Culture and Society 2 (3): 37-46. 
2006. Gender and the Haunting of the Cities (or, the Retirement of the flâneur). In The Invisible Flâneuse?: Gender, Public Space, and Visual Culture in Nineteenth-Century Paris, ed. Aruna D'Souza and Tom McDonough, 18-31. Manchester: Manchester University Press.

Woolf, Virginia. 1942. The Death of the Moth, and Other Essays. London: Hogarth Press.

Open Access This chapter is licensed under the terms of the Creative Commons Attribution 4.0 International License (http://creativecommons.org/licenses/ by $/ 4.0 /$ ), which permits use, sharing, adaptation, distribution and reproduction in any medium or format, as long as you give appropriate credit to the original author(s) and the source, provide a link to the Creative Commons licence and indicate if changes were made.

The images or other third party material in this chapter are included in the chapter's Creative Commons license, unless indicated otherwise in a credit line to the material. If material is not included in the chapter's Creative Commons licence and your intended use is not permitted by statutory regulation or exceeds the permitted use, you will need to obtain permission directly from the copyright holder.

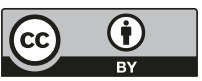

